\title{
Analiza porównawcza badań wilgotnościowych metodą chemiczną w stosunku do badań grawimetrycznych wybranych materiałów budowlanych
}

\author{
Maciej Trochonowicz, Bartosz Szostak, Daniel Lisiecki
}

\author{
Katedra Konserwacji Zabytków, Wydziat Budownictwa i Architektury, \\ Politechnika Lubelska, ul. Nadbystrzycka 40, 20-618 Lublin, m.trochonowicz@pollub.pl
}

Streszczenie: Metoda grawimetryczna, metoda bezpośrednia, uznawana jest za jedyny miarodajny sposób badania wilgotności. Funkcjonuje jednocześnie wiele metod pośrednich gdzie wynik pomiaru obarczony jest mniejszym lub większym błędem. Głównym celem artykułu jest określenie dokładności otrzymywanych wyników metodą chemiczną w stosunku do metody grawimetrycznej oraz wyznaczenie wzorów regresyjnych potrzebnych do skorygowania wyników.

Słowa kluczowe: badania wilgotnościowe, wilgoć, metoda karbidowa, metoda chemiczna, metoda grawimetryczna.

\section{Wprowadzenie}

Metody badań wilgotności masowej materiałów można podzielić na takie, w których pomiar odbywa się w sposób bezpośredni (wynik otrzymuje się na podstawie bezpośredniego wskazania narzędzia pomiarowego, wywzorcowanego w jednostkach miary mierzonej wielkości) lub pośredni (wynik otrzymuje się na podstawie bezpośredniego pomiaru innych wielkości, opierając się na znanej zależności między tymi wielkościami, a wielkością mierzoną). W budownictwie najczęściej oznaczenie wilgotności masowej wykonuje się stosując metodę laboratoryjną (pomiar bezpośredni) lub karbidową, dielektryczną, opornościową (pomiar pośredni).

W Polsce pomiar bezpośredni (laboratoryjny) uważany jest, za jedyny miarodajny sposób pomiaru wilgoci, a badania wilgotności masowej wykonywać należy w oparciu o normę [2]. Metody pośrednie pomiaru posiadają szereg ograniczeń wpływających na dokładność pomiaru. $\mathrm{Z}$ tego też powodu wyniki uzyskiwane przy ich zastosowaniu należy traktować, jako półilościowe, o charakterze informacyjnym. Przyjmuje się, że spośród metod pośrednich, najbardziej wiarygodne wyniki uzyskiwane są dzięki metodzie chemicznej (karbidowej). Dokładność pomiaru wynosi około $\pm 3 \%$. Głównym powodem niezgodności wyników $\mathrm{z}$ badaniami metodą grawimetryczną jest to, że karbid nie wchodzi w reakcję z wodą związaną chemicznie. Różnice są bardzo widoczne podczas badania materiałów silnie zasolonych i materiałów gipsowych. Pomimo dość istotnych ograniczeń badanie wilgotności metodą karbidową jest bardzo popularne na zachodzie Europy i coraz częściej stosowana w Polsce. Zdecydowanie największą zaletą metody chemicznej jest stosunkowo krótki (kilka minut) czas oznaczania wilgotności. Obecnie metoda karbidowa wykorzystywana jest najczęściej do badania wilgotności posadzek przed wbudowaniem warstw wykończeniowych.

W literaturze krajowej, poza wzmiankami o występowaniu różnic w wartościach wilgotności badanych grawimetrycznie i chemicznie, jest niewiele informacji dotyczących 
dokładności otrzymywanych wyników. Do nielicznych wyjątków należy publikacja Z. Matkowskiego i J. Adamowskiego, w której przedstawione zostały wyniki badań dla trzech materiałów (cegły, tynku cementowego i tynku wapiennego). Z badań wynika, że dokładne wyniki zostały osiągnięte jedynie dla tynku wapiennego. W przypadku pozostałych materiałów różnice w wynikach osiągniętych metodą chemiczną były wyraźnie, nawet kilkukrotnie zaniżone w stosunku do metody grawimetrycznej [4].

W związku z świadomością dużych różnic w osiąganych wynikach i niedostateczną ilością informacji w literaturze autorzy zdecydowali się na przeprowadzenie szeregu badań wilgotnościowych z użyciem obydwu metod. Założono, że badania przeprowadzone zostaną z użyciem możliwie dużej liczby materiałów o różnych wilgotnościach. Niniejszy artykuł przedstawia zestawienie wyników badań i analiz, których celem była próba wyznaczenia zależności pomiędzy wynikami osiągniętymi metodą chemiczną i grawimetryczną.

\section{Material badawczy i przygotowanie próbek}

Badania przeprowadzono na dziesięciu materiałach budowlanych o zróżnicowanych własnościach fizyko-chemicznych, aby uzyskać jak najwięcej informacji na temat metody karbidowej. Wybrano materiały konstrukcyjne (beton, beton komórkowy, skała wapienna, cegła ceramiczna i wapienno-piaskowa) oraz materiały wykończeniowe (tynk wapienny, tynk wapienno-cementowy i tynk historyczny). Zebrany materiał badawczy był różnego pochodzenia, większość z nich została nabyta jako gotowy produkt (cegła wapiennopiaskowa, cegła ceramiczna pełna, cegła klinkierowa, beton komórkowy). Niektóre z nich zostały wykonane w laboratorium uczelnianym (beton, tynk wapienny, tynk cementowowapienny). Cegła historyczna oraz tynk historyczny pochodziły $\mathrm{z}$ remontowanej XIX wiecznej kamienicy. Skała wapienna (opoka) to materiał rozbiórkowy z obiektów pochodzących z Janowca i Kazimierza nad Wisłą.

Zebrane materiały pocięto na prostopadłościany. Starano się uzyskać próbki sześcienne lub prostopadłościenne o zbliżonych wielkościach, ale z powodu gabarytów niektórych materiałów było to niemożliwe. Tynk historyczny oraz wapienny z powodu nieregularnych kształtów i niewielkiej grubości (około $3 \mathrm{~cm}$ ) został podzielony na prostopadłościany o różnych wielkościach. Próbki wysuszono do stałej masy w temperaturze $105^{\circ} \mathrm{C}$, zważono, określono ich objętość i obliczono gęstości pojedynczych próbek, a następnie wartości średnie dla każdego materiału.

Kolejnym etapem badań było zawilgacanie próbek. Pierwsza czynność było określenie maksymalnej nasiąkliwości badanych materiałów. Badania wykonano dla wszystkich materiałów, a próba badawcza liczyła trzy próbki. Do dalszych badań przyjęto wartość średnią. Określenie maksymalnej nasiąkliwości miało na celu przyjęcie zakresu wilgotności, w którym powinny się znaleźć wszystkie badane próbki danego materiału. W związku $\mathrm{z}$ tym, że planowano wyznaczenie równań linii regresji dążono do w miarę regularnego zawilgocenia próbek. Przykładowo, jeżeli maksymalna nasiąkliwość wynosiła 24\% i badano 8 próbek to starano się nasączyć próbki do wilgotności 3\%, 6\%, 9\% itd.

Problematycznym zagadnieniem było uzyskanie wilgotności materiału o dokładnej wartość. Pierwotnie założono nasączenie wszystkich próbek i powolne ich suszenie do uzyskania satysfakcjonującej masy. Pomysł ten został odrzucony ze względu na dużą nierównomierność zawilgocenia na powierzchni i wewnątrz próbki (potwierdzone doświadczalnie). Zdecydowano o nasączaniu próbek wysuszonych do stałej masy dokładnie taką ilością wody, która pozwoli na uzyskanie planowanych wilgotności masowych. Próbki owinięto folią stretch z pięciu stron tak aby jedną odsłoniętą płaszczyznę owinąć folia po zalaniu wodą. Kolejno odmierzano 
potrzebną ilość wody i zalewano próbki. Tak zabezpieczone próbki zostały odłożone na 10 dni, przy czym minimum 2 razy dziennie obracane były o $90^{\circ}$.

Podczas przygotowywania próbek do badań ze względu na uzyskane bardzo niskie nasączenie betonu i cegły klinkierowej zrezygnowano z prowadzenia dalszych badań na próbkach $\mathrm{z}$ tych materiałów.

\section{Aparatura badawcza i badania}

Do przeprowadzenia badań metodą chemiczną wykorzystano wilgotnościomierz karbidowy WK-1 firmy Tanel. W skład zestawu wchodzi: pojemnik pomiarowy z manometrem, waga elektryczna, łyżeczka, szalka, ciężarki 5g (2szt.), moździerz oraz szczotka do czyszczenia urządzenia. Masa próbki badanego materiału, zakres pomiarowy manometru i wymiary komory pomiarowej zostały tak dobrane, że manometr jest wyskalowany bezpośrednio w procentach wilgotności względnej [1]. Do wykonania badań metodą grawimetryczną wykorzystano elektroniczną wagę laboratoryjną RADWAG i suszarkę ECOCELL.

W związku z koniecznością stworzenia optymalnych warunków badania zdecydowano, że obydwa oznaczenia wykonane zostaną jednocześnie. Zawilgocone próbki rozpakowano i rozdrobniono mechanicznie, a następnie materiał został przesiany. Odważone próbki wsypywano do komory pomiarowej urządzenia karbidowego wraz z odpowiednią naważką karbidu. Jednocześnie reszta przesianego materiału była ważona i umieszczana $\mathrm{w}$ suszarce (oznaczanie wilgotności metodą wago-suszarkową).

Pozostawiając pojemnik w poziomej pozycji dokręcono mocno śrubę dociskową powodując szczelne zamknięcie pojemnika. Potrząsano kilkukrotnie w dół i w górę pojemnik, a następnie odwracano i powtarzano potrząsanie. Czynność tę wykonywano co około jedną minutę. Po około 4 minutach odczytywano wynik. Przyrząd wskazuje wilgotność względną w procentach, która został przeliczona na wilgotność bezwzględną.

\section{Wyniki badań}

Po wykonaniu oznaczeń wilgotności metodą chemiczną uzyskane wartości wilgotności względne przeliczone zostały na wartości bezwzględne. Całość uzyskanych wyników, różnice pomiędzy wilgotnościami oraz procentowe błędy zestawiono w tabeli 1 .

\section{Analiza wyników}

Analizę wyników przeprowadzono osobno dla każdego materiału oraz w zestawieniu zbiorczym. Obliczenia potrzebne do wyznaczenia linii regresji oraz wykresy zostały wykonane w programie Statistica. Pozostałe wykresy oraz tabele zostały sporządzone w programie Microsoft Office Excel.

Predykcja to szacowanie wartości jednej zmiennej lub zmiennych wtedy, gdy zmienne są ze sobą skorelowane. Korelacja pomiędzy zmiennymi nie musi mieć charakteru liniowego, dlatego oprócz liniowych, wyznaczono wielomianowe i logarytmiczne. Predykcja na podstawie linii regresji to poszukiwanie linii regresji najlepiej dopasowanej do wartości zmiennej zależnej (wilgotność bezwzględna metody grawimetrycznej) na podstawie zmiennej niezależnej (wilgotność bezwzględna metody chemicznej) [3]. Najlepiej dopasowana linia regresji to taka, która minimalizuje sumę kwadratów miedzy wartościami pomierzonymi, a ich wartościami przewidywanymi (tzw. kryterium najmniejszych kwadratów) [3]. 
Tabela 1. Wyniki badań wilgotności metodami chemiczną i wago-suszarkową

\begin{tabular}{|c|c|c|c|c|c|c|c|c|c|}
\hline \multicolumn{5}{|c|}{ Opoka wapnista - Kazimierz nad Wisłą } & \multicolumn{5}{|c|}{ Cegła ceramiczna pełna } \\
\hline \multirow{2}{*}{$\begin{array}{l}\mathrm{Nr} \\
\text { próbki }\end{array}$} & Wag-susz & Chemiczna & Różnica & Błąd & \multirow{2}{*}{$\begin{array}{c}\mathrm{Nr} \\
\text { próbki }\end{array}$} & \multirow{2}{*}{$\begin{array}{c}\text { Wag-susz } \\
{[\%]}\end{array}$} & \multirow{2}{*}{$\begin{array}{c}\text { Chemiczna } \\
{[\%]}\end{array}$} & \multirow{2}{*}{$\begin{array}{c}\text { Różnica } \\
{[\%]}\end{array}$} & \multirow{2}{*}{$\begin{array}{c}\text { Błąd } \\
{[\%]}\end{array}$} \\
\hline & [\%] & [\%] & [\%] & {$[\%]$} & & & & & \\
\hline 1 & 2,82 & 1,83 & 0,99 & 35,0 & 1 & 2,65 & 1,42 & 1,23 & 46,4 \\
\hline 2 & 5,78 & 3,84 & 1,93 & 33,5 & 2 & 5,62 & 4,60 & 1,02 & 18,1 \\
\hline 3 & 8,93 & 7,18 & 1,74 & 19,5 & 3 & 8,91 & 7,76 & 1,15 & 12,9 \\
\hline 4 & 11,94 & 9,41 & 2,53 & 21,2 & 4 & 11,98 & 8,81 & 3,17 & 26,4 \\
\hline 5 & 15,04 & 12,61 & 2,43 & 16,1 & 5 & 13,26 & 10,74 & 2,52 & 19,0 \\
\hline 6 & 17,72 & 14,68 & 3,04 & 17,1 & 6 & 14,91 & 11,36 & 3,55 & 23,8 \\
\hline \multirow[t]{2}{*}{7} & 19,79 & 16,28 & 3,51 & 17,7 & 7 & 16,97 & 14,94 & 2,03 & 11,9 \\
\hline & & & & & 8 & 18,98 & 15,74 & 3,24 & 17,1 \\
\hline \multicolumn{5}{|c|}{ Tynk wapienny } & \multicolumn{5}{|c|}{ Cegła ceramiczna pełna historyczna } \\
\hline \multirow{2}{*}{$\begin{array}{c}\mathrm{Nr} \\
\text { próbki }\end{array}$} & Wag-susz & Chemiczna & Różnica & Błąd & \multirow{2}{*}{$\begin{array}{c}\mathrm{Nr} \\
\text { próbki }\end{array}$} & Wag-susz & Chemiczna & Różnica & Błąd \\
\hline & {$[\%]$} & {$[\%]$} & {$[\%]$} & {$[\%]$} & & {$[\%]$} & {$[\%]$} & {$[\%]$} & {$[\%]$} \\
\hline 1 & 2,67 & 1,21 & 1,45 & 54,4 & 1 & 2,82 & 1,83 & 0,99 & 35,0 \\
\hline 2 & 5,03 & 2,56 & 2,47 & 49,1 & 2 & 5,85 & 4,60 & 1,25 & 21,3 \\
\hline 3 & 8,45 & 5,60 & 2,85 & 33,8 & 3 & 8,77 & 6,84 & 1,93 & 22,0 \\
\hline 4 & 10,75 & 6,95 & 3,80 & 35,3 & 4 & 11,76 & 9,17 & 2,59 & 22,0 \\
\hline 5 & 16,10 & 11,23 & 4,86 & 30,2 & 5 & 12,77 & 9,89 & 2,88 & 22,5 \\
\hline 6 & 20,15 & 14,42 & 5,74 & 28,5 & 6 & 13,70 & 10,62 & 3,08 & 22,5 \\
\hline \multirow[t]{2}{*}{7} & 20,11 & 15,47 & 4,64 & 23,1 & 7 & 14,95 & 11,61 & 3,34 & 22,4 \\
\hline & & 8 & \multicolumn{2}{|c|}{18,10} & \multicolumn{2}{|c|}{14,16} & 3,95 & \multicolumn{2}{|c|}{21,8} \\
\hline \multicolumn{5}{|c|}{ Tynk cementowo - wapienny } & \multicolumn{5}{|c|}{ Cegła wapienno piaskowa } \\
\hline \multirow{2}{*}{$\begin{array}{c}\mathrm{Nr} \\
\text { próbki }\end{array}$} & Wag-susz & Chemiczna & Różnica & Błąd & \multirow{2}{*}{$\begin{array}{c}\mathrm{Nr} \\
\text { próbki }\end{array}$} & Wag-susz & Chemiczna & Różnica & Błąd \\
\hline & [\%] & {$[\%]$} & {$[\%]$} & {$[\%]$} & & {$[\%]$} & {$[\%]$} & {$[\%]$} & {$[\%]$} \\
\hline 1 & 1,94 & 0,91 & 1,03 & 53,1 & 1 & 2,83 & 1,47 & 1,36 & 48,1 \\
\hline 2 & 5,70 & 3,15 & 2,56 & 44,9 & 2 & 3,88 & 1,94 & 1,94 & 50,1 \\
\hline 3 & 7,41 & 4,49 & 2,92 & 39,4 & 3 & 5,59 & 3,20 & 2,39 & 42,7 \\
\hline 4 & 7,46 & 4,77 & 2,69 & 36,1 & 4 & 7,78 & 5,04 & 2,74 & 35,2 \\
\hline 5 & 8,86 & 5,93 & 2,93 & 33,1 & 5 & 9,86 & 7,07 & 2,79 & 28,3 \\
\hline 6 & 10,09 & 6,38 & 3,70 & 36,7 & 6 & 11,74 & 8,58 & 3,16 & 26,9 \\
\hline 7 & 11,78 & 7,99 & 3,79 & 32,2 & & & & & \\
\hline \multicolumn{5}{|c|}{ Tynk historyczny wapienny } & \multicolumn{5}{|c|}{ Beton komórkowy } \\
\hline $\mathrm{Nr}$ & Wag-susz & Chemiczna & Różnica & Błąd & $\mathrm{Nr}$ & Wag-susz & Chemiczna & Różnica & Błąd \\
\hline próbki & [\%] & {$[\%]$} & [\%] & {$[\%]$} & próbki & {$[\%]$} & {$[\%]$} & {$[\%]$} & {$[\%]$} \\
\hline 1 & 2,57 & 0,60 & 1,97 & 76,5 & 1 & 4,23 & 2,8 & 1,40 & 33,1 \\
\hline 2 & 5,51 & 2,99 & 2,53 & 45,8 & 2 & 9,08 & 7,1 & 2,01 & 22,1 \\
\hline 3 & 7,48 & 4,06 & 3,42 & 45,7 & 3 & 14,06 & 11,6 & 2,43 & 17,3 \\
\hline 4 & 8,61 & 6,04 & 2,57 & 29,8 & 4 & 19,54 & 17,1 & 2,44 & 12,5 \\
\hline 5 & 10,55 & 9,05 & 1,50 & 14,2 & 5 & 25,11 & 22,9 & 2,26 & 9,0 \\
\hline 6 & 11,83 & 9,35 & 2,48 & 21,0 & 6 & 30,15 & 26,6 & 3,56 & 11,8 \\
\hline 7 & 15,63 & 12,11 & 3,52 & 22,5 & 7 & 34,62 & 29,4 & 5,25 & 15,2 \\
\hline 8 & 17,50 & 14,55 & 2,95 & 16,9 & 8 & 57,04 & 46,0 & 11,06 & 19,4 \\
\hline
\end{tabular}

Celem analitycznej oceny poprawności predykcji oblicza się błąd prognozy MAPE. Błąd MAPE jest podstawowym miernikiem prawidłowości obliczeń i uważa się go 
za najbardziej miarodajny. Używany do wyboru najlepszego modelu predykcyjnego. Jeżeli odbiorca nie ma własnych kryteriów, przyjmuje się, że jeżeli błąd MAPE wynosi: MAPE $\leq 1 \%$ prognozy doskonałe; $1 \%<$ MAPE $\leq 3 \%$ prognozy wysoce dokładne; $3 \%<$ MAPE $\leq 5 \%$ prognozy dobre; $5 \%<$ MAPE $\leq 10 \%$ prognozy dostateczne; $10 \%<$ MAPE $\leq 15 \%$ prognozy mało dokładne, ale mogą być przyjęte dopuszczalne; MAPE $>15 \%$ prognozy niedokładnie, nie powinny być przyjmowane3. Obliczenia przeprowadzono na podstawie prognozowania metodą uogólnionych modeli addytywnych. Poniżej przedstawiono wykres oraz równanie linii regresji, dla którego uzyskano najniższy wskaźnik MAPE.

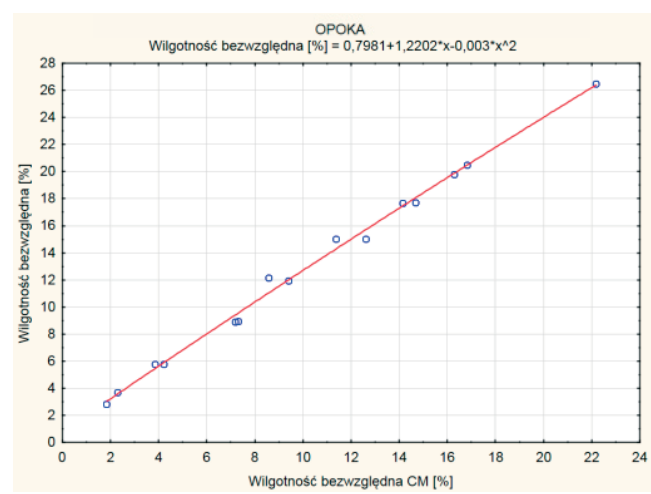

Wskaźnik MAPE 3,49\%

Równanie linii regresji: $v 4=0,7981+1,2202 *(v 6)-0,003 *(v 6)^{2}$

$v 4$ - wilgotność bezwzględna, $\nu 6$ - wilgotność bezwzględna metody chemicznej.

Rys. 1. Wykres ilustrujący wartości pomierzone wraz z wielomianową linią regresji dla opoki wapnistej

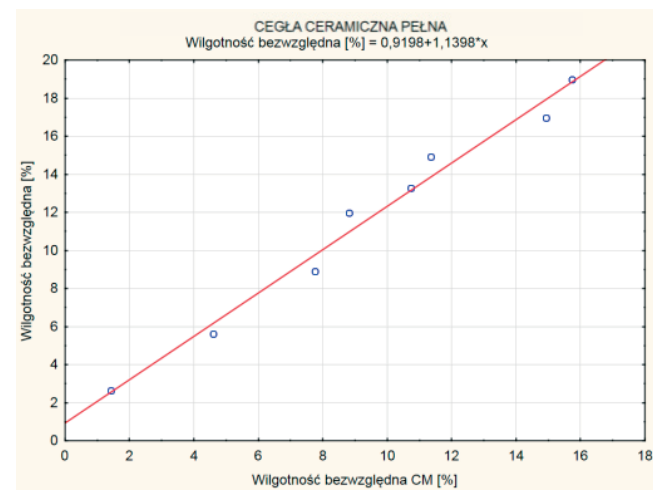

Wskaźnik MAPE 4,96\%

Równanie linii regresji: $v 4=0,9198+1,398 *(v 6)$

Rys. 3. Wykres ilustrujący wartości pomierzone wraz z liniową linią regresji dla cegły ceramicznej pełnej



Wskaźnik MAPE 2,94\%

Równanie linii regresji: $v 4=0,8453+1,5469 *(v 6)-0,034 *(v 6)^{2}$

$v 4$ - wilgotność bezwzględna,

v6 -- wilgotność bezwzględna metody chemicznej.

Rys. 2. Wykres ilustrujący wartości pomierzone wraz z wielomianową linią regresji dla cegły wapienno-piaskowej

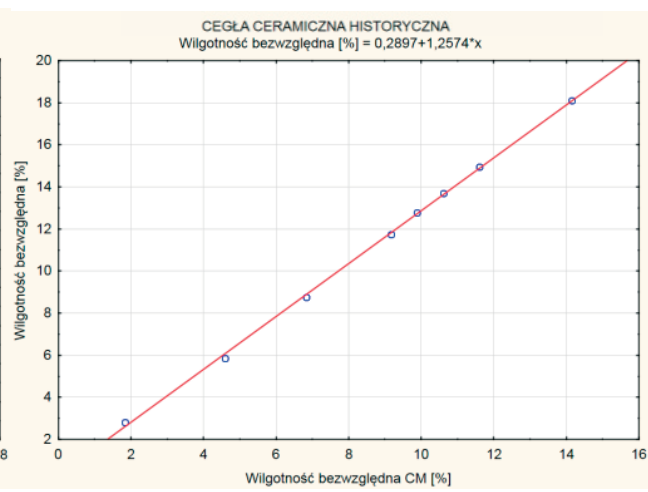

Wskaźnik MAPE 1,89\%

Równanie linii regresji: $v 4=0,2897+1,2574 *(v 6)$

Rys. 4. Wykres ilustrujący wartości pomierzone wraz z liniową linią regresji dla cegły ceramicznej historycznej 


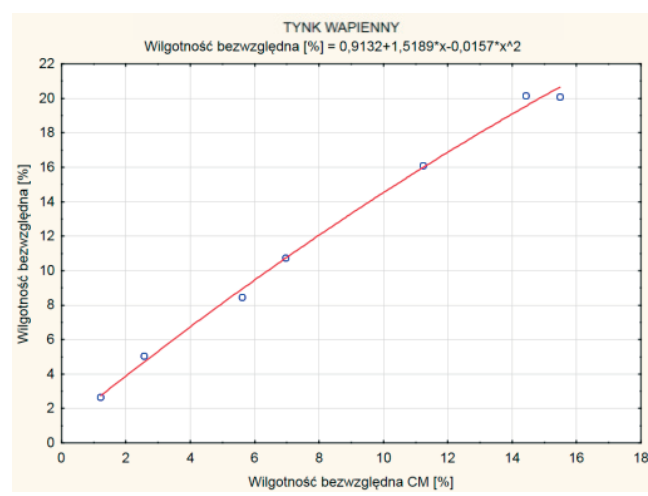

Wskaźnik MAPE 3,06\%

Równanie linii regresji: $v 4=0,9132+1,5189 *(v 6)-0,0157 *(v 6)^{2}$

Rys. 5. Wykres ilustrujący wartości pomierzone wraz z wielomianową linią regresji dla tynku wapiennego



Wskaźnik MAPE 5,20\%

Równanie linii regresji: $v 4=2,3065+1,0421 *(v 6)$

Rys. 7. Wykres ilustrujący wartości pomierzone wraz z liniową linią regresji dla tynku historycznego

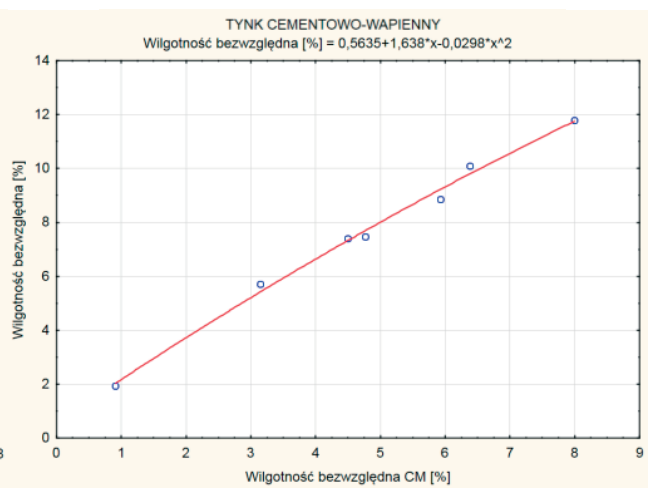

Wskaźnik MAPE 3,03\%

Równanie linii regresji: $v 4=0,5635+1,638 *(v 6)-0,0298 *(v 6)^{2}$

Rys. 6. Wykres ilustrujący wartości pomierzone wraz z wielomianową linią regresji dla tynku cementowo-wapiennego

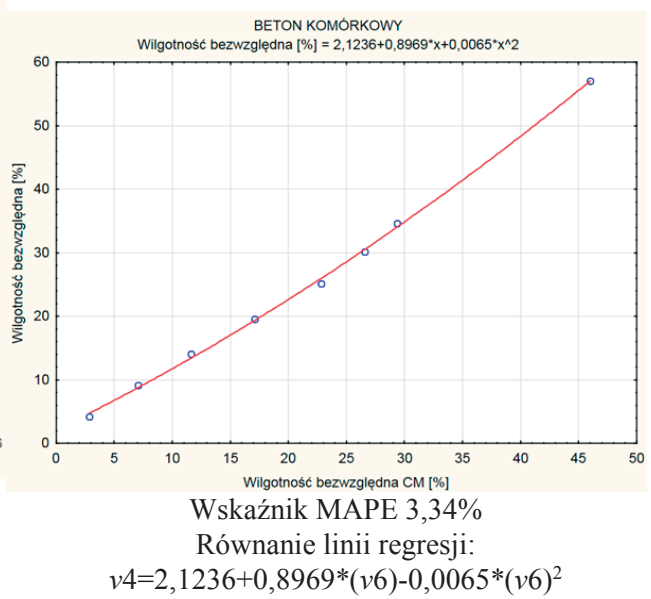

Rys. 8. Wykres ilustrujący wartości pomierzone wraz z wielomianową linią regresji dla betonu komórkowego

\section{Analiza zbiorcza}

Przeprowadzono dwie analizy, do których wzięto wszystkie otrzymane wyniki (bez podziału na materiał). Pierwsza z nich polega na uzależnieniu wilgotności bezwzględnej od gęstości materiału i wilgotności bezwzględnej metody chemicznej. Druga natomiast pozwala wyznaczyć wilgotność bezwzględną tylko od wartości wilgotności otrzymanej w metodzie karbidowej.

\section{Analiza I (z uwzględnieniem gęstości)}

Na podstawie prognozowania metodą uogólnionych modeli addytywnych wyznaczono wzór regresyjny do obliczenia wilgotności bezwzględnej na podstawie wilgotności bezwzględnej metody chemicznej oraz gęstości materiału. 


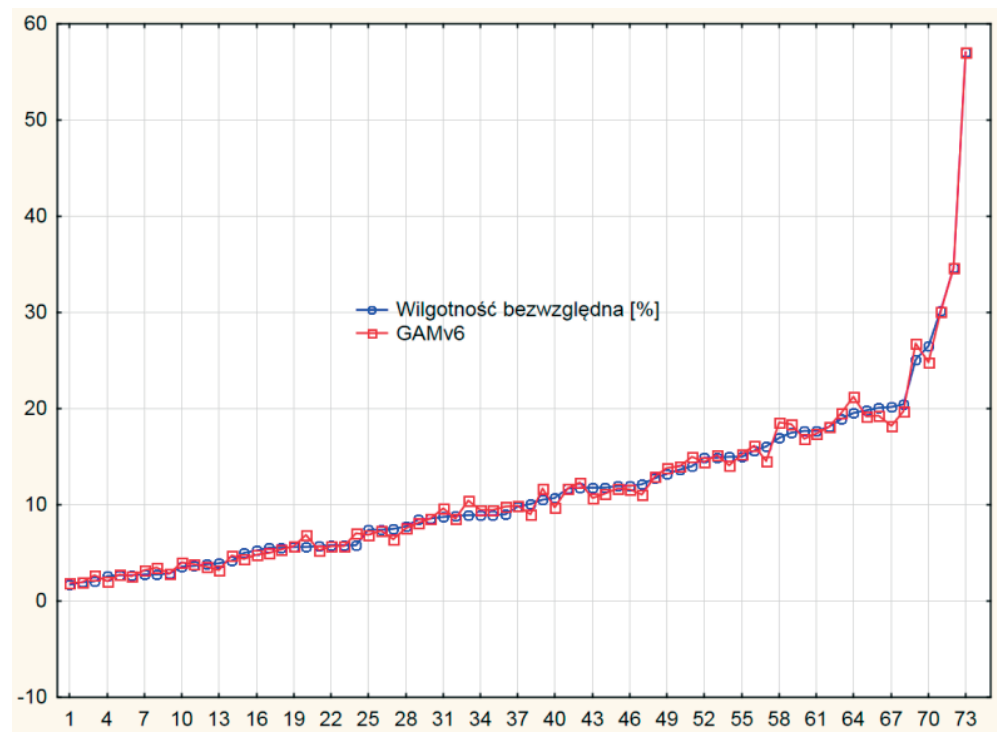

Rys. 9. Wykres wartości rzeczywistych i prognozowanych

Powyższe wykresy przedstawią relacje pomiędzy rzeczywistymi wynikami wilgotności bezwzględnej uzyskanymi metodą karbidową (kwadratowy znaczek graficzny) a prognozowaną wartością wilgotności bezwzględnej materiału (okrągły znaczek graficzny). Na podstawie przeprowadzonych obliczeń błąd prognozy MAPE wynosi 6,90\% oraz wyznaczono wzór regresyjny do obliczania wilgotności bezwzględnej.

$$
v 4=e^{\left(20,9183-37,2051(v 2)+0,0171(v 6)-6,5086(v 2)^{3}+0,2195(v 2)^{5}+9,3367 \ln (v 2)+23,1948(v 2)^{2}-0,003(v 6)^{2}+0,0574(v 6)^{-3}+0,7052 \ln (v 6)\right)}
$$

gdzie: $v 2$ - gęstość materiału; v4 - wilgotność bezwzględna; v6 - wilgotność bezwzględna metody chemicznej.

\section{Analiza II (bez uwzględnienia gęstości)}

Na podstawie prognozowania metodą uogólnionych modeli addytywnych wyznaczono wzór regresyjny do obliczenia wilgotności bezwzględnej na podstawie wilgotności bezwzględnej metody CM.

Powyższe wykresy przedstawiają relacje pomiędzy rzeczywistymi wynikami wilgotności bezwzględnej uzyskanymi metodą karbidową (kwadratowy znaczek graficzny) a prognozowaną wartością wilgotności bezwzględnej materiału (okrągły znaczek graficzny). Na podstawie obliczeń otrzymano błąd prognozy MAPE wynoszący 9,12\%, który można uznać, jako dostateczny. Wynik ten jest jednak wyższy niż w poprzedniej analizę, co oznacza mniej dokładne prognozowanie wyniku, jednak pozwala na wyznaczenie wartości bezwzględnej bez uwzględniania gęstości materiału.

$$
v 4=e^{\left(0,8842+0,0687(v 6)-0,0014(v 6)^{2}+0,0196(v 6)^{-3}+0,4796 \ln (v 6)\right)}
$$

gdzie: $v 4$ - wilgotność bezwzględna; $v 6$ - wilgotność bezwzględna metody CM. 


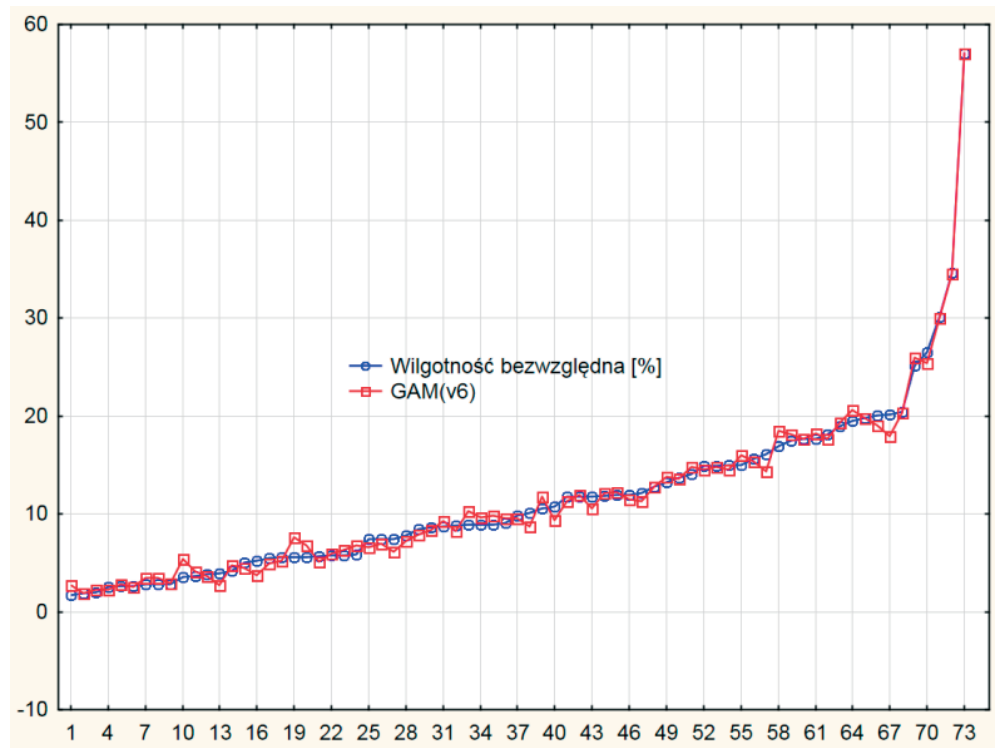

Rys. 10. Wykres wartości rzeczywistych i prognozowanych

\section{Wnioski}

1. We wszystkich przypadkach wilgotności otrzymane metodą chemiczną są zaniżone względem wyników metody grawimetrycznej.

2. W zależności od badanego materiału błąd metody karbidowej jest różny.

3. Przy małych wilgotnościach skala błędu pomiaru metodą chemiczną jest wyraźnie większa i dotyczy wszystkich badanych materiałów.

4. Na podstawie przeprowadzonych obliczeń wyznaczono wzory regresyjne korygujące błąd pomiarowy zależny od wilgotności bezwzględnej metody chemicznej dla danego materiału (błąd MAPE wynosi 2-6\% co świadczy o prognozie wysoce dobrej).

5. Ze względu na niższą wartość współczynnika błędu MAPE zaleca się stosowanie wzorów regresji wyznaczonych dla pojedynczych materiałów. Wzór ogólny może być stosowany jedynie dla materiałów nie objętych badaniami.

6. Skala błędu metody chemicznej jest zbyt duża, aby mogła być stosowana w budownictwie bez korygowania wyniku.

\section{Literatura}

1. Instrukcja obsługi wilgotnościomierza karbidowego WK-1 firmy Tanel.

2. PN-EN ISO 12570. Cieplno-wilgotnościowe właściwości materiałów i wyrobów budowlanych. Określanie wilgotności przez suszenie w podwyższonej temperaturze.

3. Rogalska M. Wieloczynnikowe modele w prognozowaniu czasu procesów budowlanych. Politechnika Lubelska, Lublin 2016.

4. Adamowski J., Matkowski Z. Ocena skuteczności osuszania ścian murowanych. Materiały Budowlane 4 (1999) 131-137. 


\title{
Comparative analysis of survey on humidity carried out by chemical way in proportion to gravimetric survey on selected building materials
}

\author{
Maciej Trochonowicz, Bartosz Szostak, Daniel Lisiecki
}

Lublin University of Technology, Faculty of Civil Engineering and Architecture, Chair of Historic Buildings Preservation, m.trochonowicz@pollub.pl

\begin{abstract}
The gravimetric method is considered to be the only reliable method used to measure the moisture content of a certain material. The main purpose of this article is to determine the accuracy scale of the results drawn from the chemical method being applied to the most basic building materials and establishing regression patterns necessary to correct the results of the calcium carbide method.

Keywords: humidity, humidity inspection, carbide method, chemical method, gravimetric method.
\end{abstract}


